\title{
Corrigendum: Hauntings, homeopathy, and the Hopkinsville Goblins: using pseudoscience to teach scientific thinking
}

\author{
Rodney Schmaltz ${ }^{1 *}$ and Scott O. Lilienfeld ${ }^{2}$ \\ ${ }^{1}$ Department of Psychology, MacEwan University, Edmonton, AB, Canada, ${ }^{2}$ Department of Psychology, Emory University, \\ Atlanta, GA, United States
}

Keywords: scientific thinking, skepticism, pseudoscience, teaching resources, introductory psychology

\section{OPEN ACCESS}

Edited and reviewed by: Ana Lucia Pereira

Ponta Grossa State University, Brazil

*Correspondence:

Rodney Schmaltz

rodney.schmaltz@macewan.ca

Specialty section:

This article was submitted to

Educational Psychology,

a section of the journal

Frontiers in Psychology

Received: 21 September 2017

Accepted: 30 October 2017

Published: 07 November 2017

Citation:

Schmaltz R and Lilienfeld SO (2017)

Corrigendum: Hauntings, homeopathy, and the Hopkinsville

Goblins: using pseudoscience to teach scientific thinking.

Front. Psychol. 8:1982.

doi: 10.3389/fpsyg.2017.01982

\section{A corrigendum on}

Hauntings, homeopathy, and the Hopkinsville Goblins: using pseudoscience to teach scientific thinking

by Schmaltz, R., and Lilienfeld, S. O. (2014). Front. Psychol. 5:336. doi: 10.3389/fpsyg.2014.00336

In the original article, there was an incorrect citation. In the third paragraph under the heading, "Aliens and Goblins", the reference to Davis and Bloecher (1978) is incorrect. The reference should be Nickell (2006).

A correction has been made to this section:

The Hopkinsville entities have a decidedly earthly explanation. It is plausible, if not likely, that the "aliens" were Great Horned Owls, and there is some evidence that the eyewitnesses may have been intoxicated during the "alien attack" (Nickell, 2006). Students usually find the true story of the events amusing; and this example can lead naturally into a discussion on Area 51, the Greys, or other otherworldly interests (Nickell, 2012; Leman and Cinnirella, 2013). The authors apologize for this error and state that this does not change the scientific conclusions of the article in any way.

Conflict of Interest Statement: The authors declare that the research was conducted in the absence of any commercial or financial relationships that could be construed as a potential conflict of interest.

Copyright () 2017 Schmaltz and Lilienfeld. This is an open-access article distributed under the terms of the Creative Commons Attribution License (CC BY). The use, distribution or reproduction in other forums is permitted, provided the original author(s) or licensor are credited and that the original publication in this journal is cited, in accordance with accepted academic practice. No use, distribution or reproduction is permitted which does not comply with these terms. 